\title{
流木木酢液ベンゼン抽出物の燻臭成分とその抗酸化性
}

\author{
宮川雄太 ${ }^{\S}$, 宮川富三雄, 西山由隆*，村 清司*，徳江千代子* \\ 開発工事株式会社 茅ヶ崎研究所 \\ *東京農業大学 応用生物科学部 栄養科学科
}

\section{Antioxidative Smoke Flavor Extraction in Wood Vinegar Prepared from Drift Wood}

Yuta Miyakawa ${ }^{\S}$, Fumio Miyagawa, Yoshitaka Nishiyama*, Kiyoshi Mura* and Chiyoko Tokue*

Kaihatukozi CO., Ltd., chigasaki laboratory, 328-3, Amanuma, Chigasaki-shi, Kanagawa, 253-0004, Japan *Tokyo University of Agriculture, Faculty of Applied Bioscience, Department of Nutrition,

1-1-1, Sakuragaoka, Setagaya-ku, Tokyo 156-8502, Japan

\begin{abstract}
The purpose of this research is to utilize wood vinegar manufactured from drift wood as a food additive as one of the effective utilization methods, removal of formaldehyde and methanol from wood vinegar recovered from drift wood, and smoke flavors and their antioxidant properties have been examined. Extracted wood vinegar from drift wood with benzene fractionated to acidic, phenolic and neutral Fraction using $5 \% \mathrm{NaHCO}_{3}$ and $5 \% \mathrm{NaOH}$. Twenty-three main smoke flavors were identified by GC and GC-MS. Each content of formaldehyde and methanol was 5 ppm or less in any fraction and the content of organic acids were $0.01 \%$ or less in any fraction. Phenolic fraction showed most strong antioxidative activity and DPPH radical scavenging activity. Guaiacol derivatives, 2,6-dimethoxy phenol derivatives showed strong antioxidative activity and radical scavenging activity. Wood vinegar using drift wood as a row material can be manufactured without consuming forest resources compared with conventional wood vinegar. In additional, the smoke flavors extraction from wood vinegar has possibility for application to food as a safer product than conventional wood vinegar.

(Received Mar. 3, 2003 ; Accepted Aug. 11, 2003)
\end{abstract}

木酢液は木炭を製造する際，発生する煙を泠却した赤褐 色の水溶性液体である. 古くから煄製食品の原料 ${ }^{122}$ とし て用いられ, 経験的に殺菌作用, 防臭効果, 抗酸化作用が 知られていた。 その後学術的な追試により殺菌作用 ${ }^{3) \sim 5)}$, 抗酸化作用 ${ }^{5) \sim 7)}$ のあることが報告された。

しかし木酢液は殺菌作用, 抗酸化作用を示すむののホル ムアルデヒド，メ夕ノールが含有されているため ${ }^{899}$, その まま食品へ利用することは不適切と思われる ${ }^{10}$.

クヌギ，十ラ等の広葉樹 ${ }^{11}$ やスギ，マッ等の針葉樹(2)13) から製造された木酢液には 200 種から 300 種の成分 ${ }^{5 / 8) 12}$ があるとされ，特有な燻臭を有している。

通常，木酢液の原料となる樹木は自生している成木を人 の手で伐採して抢り，近年，自然破壊や環境污染が深刻化 する中，現在の方法で原料を調達していくと，今後，ます ます森林破壊が進むと考えられ，伐採した樹木を原料とし ない木酶液の製造が必要になってくると考えられる。

福島県会津地方の水力発電所夕゙ムに流れてくる流木量は

干253-0004 神奈川県茅ヶ崎市甘沼 328-3

* 156-8502 東京都世田谷区桜丘 1-1-1

$\S$ 連絡先 (Corresponding author), yuta miyagawa@kaiko.co.jp
年間 $5000 \sim 6000 \mathrm{~m}^{3}$ になり，その流木から製造される木䣷 液量は年間約 $3600 \mathrm{~L}$ にも上る.

流木は水力発電所夕゙ムから水を放流する際, 障害となっ て発電に支障を与えたり, ダムの貯水機能を低下させる原 因となる，本来，流木は廃棄物として処理されてきが，山 間部に処分場や処理設備を十分に確保できない等の問題が あることから流木の再資源化として木酢液を製造する事を 考案した。

そこで本研究では流木木酢液の有効利用の 1 つとして食 品へ利用することを目的に流木酰液からホルムアルデヒ ド, メ夕ノールを除去すると共に燼臭成分之その抗酸化性 について検討した。

\section{実 験 方 法}

\section{1. 材 料}

流木木酢液は福島県会津地方の水力発電所夕゙ムに流れて くる流木（ブナ, マッ, スギ）を用いて次の手順で製造し た。

流木を天日干しし, 一定の長さ $(110 \mathrm{~cm})$ に切断後, 炭 釜（容積 $5.4 \mathrm{~m}^{3}$ ) に入れ，釜の温度 $400^{\circ} \mathrm{C}$, 煙突 $80^{\circ} \mathrm{C}$ に保 
持しながら 48 時間煙を採取した。その後しばらく放置し て 3 層に分離させ，中間層（粗木酢液）を採取し，6 ケ月以 上静置後, 濾過した流木木䣷液 ( $\mathrm{pH} 2.53$, 比重 1.006 , 水分 $94.9 \%$ ，ホルムアルデヒド $510 \mathrm{ppm}$, メタノール $0.19 \%$ )を 材料とした。

\section{2. 流木木酢液からの抽出と分画法}

流木木酢液 $100 \mathrm{~m} l$ にベンゼン $200 \mathrm{~m} l$ を加え，室温にて 30 分間, 2 回振とう抽出を行ない, 得られた抽出液に無水 硫酸ナトリウムを加え, 脱水し, 無水硫酸ナトリウム除去 後, ロータリーエバポレータで冷却器温度 $4{ }^{\circ} \mathrm{C} \sim 5^{\circ} \mathrm{C}$, 減圧 下 $140 \sim 130 \mathrm{mmHg}$, 浴温 $50^{\circ} \mathrm{C}$ の条件により溶媒除去した むのをベンゼン抽出物とし，これをホルムアルデヒド，メ 夕ノール分析及び有機酸類分析に供した。 また新たに流木 木酢液からベンゼン抽出した抽出液に $5 \%$ 炭酸水素ナトリ ウム, $5 \%$ 水酸化ナトリウムをそれぞれ加えて振とう抽出 を行ない, 得られた水層に塩酸を加えて酸性にした後, 再 度等量のベンゼンで室温にて 30 分間, 2 回振とう抽出を行 ない，同条件で溶媒を除去したものを酸性部，フェノール 部, 中性部として分画した。

\section{3. ホルムアルデヒドの分析}

流木木酢液のベンゼン抽出物に $50 \%(\mathrm{v} / \mathrm{v})$ エタノール 溶液 $100 \mathrm{ml}$ を加えて溶解したものを試料とし，アセチル

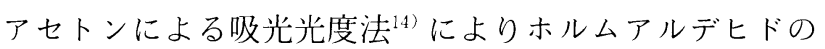
残存の有無を確認した.

\section{4. メタノールの分析}

流木木酢液のベンゼン抽出物に $99.5 \%$ エタノール 100 $\mathrm{m} l$ を加えて溶解したものを試料とし, 以下の条件で GC 分析を行ないメタノールの残存の有無を確認した。

機器: Shimadzu GC-14B (FID), カラム: Gaskuropak 55 ( $80 \sim 100$ mesh, $3 \mathrm{~mm} \times 2 \mathrm{~m}$, ジーエルサイエンス), カ ラム温度: $120^{\circ} \mathrm{C}$, 注入口温度 : $250^{\circ} \mathrm{C}$, 検出器温度 : $250^{\circ} \mathrm{C}$, キャリアーガス: $\mathrm{He}$

\section{5. 有機酸類の分析}

流木木䣷液のベンゼン抽出物に $50 \%(\mathrm{v} / \mathrm{v})$ エタノール $100 \mathrm{~m} l$ を加えて溶解したものを試料とし, 以下の条件で HPLC 分析を行ない，流木木䣷液及び残渣と比較した。

機器 : 島津, LC-10AD, カラム : Shodex RSpak C-811 $\left(8 \mathrm{~mm} \times \mathrm{L} 500 \mathrm{~mm}\right.$, 昭和電工), 力ラム温度 ; $40^{\circ} \mathrm{C}$, 移動相 : $3 \mathrm{mmol} / \mathrm{L}$ 過塩素酸, 反応液 : $0.2 \mathrm{mM}$ ブロムチモールブ ルー含有 $15 \mathrm{mM}$ リン酸水素二ナトリウム溶液, 測定波長 : $445 \mathrm{~nm}$, 流速: 移動相 $1.0 \mathrm{ml} / \mathrm{min}$, 反応液 $1.4 \mathrm{ml} / \mathrm{min}$

\section{6. 燻臭成分の分析及び同定}

流木木酢液のベンゼン抽出酸性部, フェノール部, 中性 部それぞれに 99.5\% エ夕ノール $100 \mathrm{~m} l$ を加えて溶解した ものを試料とし，それぞれの燻臭成分を以下の条件で GC 及び GC-MS 分析に供した。

\section{(1) 機器分析}

機器: 島津, GC-1700 (FID), カラム : CBP-Hicap (I.D.
$0.22 \mathrm{~mm} \times 25 \mathrm{~m}$, 島津), キャリアガス : N2, カラム温度 : $60^{\circ} \mathrm{C}$ か $5^{\circ} \mathrm{C} / \min$ で $200^{\circ} \mathrm{C}$ まで昇温, 注入口温度： $230^{\circ} \mathrm{C}$, 検出器温度 : $230^{\circ} \mathrm{C}$

(2) GC-MS 分析

機器 : 島津 GC-MS QP-5050A，カラム : DB-WAX（I.D. $0.32 \mathrm{~mm} \times 30 \mathrm{~m}, \mathrm{~J} \& \mathrm{~W}$ 社), キャリアガス : He, カラム温 度 : $50^{\circ} \mathrm{C}$ から $10^{\circ} \mathrm{C} / \mathrm{min}$ で $220^{\circ} \mathrm{C}$ まで昇温, 注入口温度： $230^{\circ} \mathrm{C}$, 検出器温度 : $230^{\circ} \mathrm{C}$, イオン化電圧 $(\mathrm{EI}): 70 \mathrm{eV}$, ス キャンレンジ : $\mathrm{m} / \mathrm{z}=29 \sim 500$

成分の同定は下記に示した標準品を用いて，その保持時 間 $\left(t_{\mathrm{R}}\right)$ とマスフラグメントの值の一致により行なった.

\section{7. 標準品}

(1) フェノール類

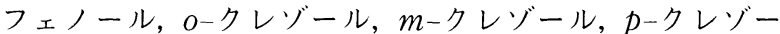
ル，グアヤコール，マルトール，バニリン，アセトバニロ ンは和光純薬(株) から，クレオゾール，4-エチルグアヤ コール, 2,6-ジメトキシフェノール, 2,6-ジメトキシ-4-メ チルフェノール, アセトシリンゴン, シリンガアルデヒド は東京化成工業(株) から，4-アリル-2,6-ジメトキシフェ ノールはアルドリッチ・ジャパン(株) 加それぞれ購入 した.

(2) ケトン類

2-シクロペンテン-1-オン，3-メチル-2-シクロペンテ， ン, シクロテンはアルドリッチ・ジャパン(株) から購入し た。

(3) フラン類

2-フラルアルデヒド， 2-アセチルフラン，5-メチルフル フラールはアルドリッチ・ジャパン（株）から購入した。

(4) その他

$\gamma$-ブチロラクトンは和光純薬(株) から，2-フォルミルピ ロールはアルドリッチ・ジャパン(株) からそれぞれ購入 した.

\section{8. 抗酸化測定}

(1) リノール酸- $\beta$-カロテン溶液を用いた抗酸化測定 抗酸化測定は津志田ら ${ }^{15)}$ の方法を一部改良し用いた。す なわち, $0.5 \mathrm{ml}$ の $\beta$-カロテン溶液 $(10 \mathrm{mg} / 10 \mathrm{ml}$ クロロホ ルム), $0.2 \mathrm{~m} l$ のリノール酸溶液 $(1 \mathrm{~g} / 10 \mathrm{~m} l$ クロロホル ム), $1.0 \mathrm{~m} l$ のツイーン 40 溶液 $(2 \mathrm{~g} / 10 \mathrm{ml}$ クロロホルム) をそれぞれ $200 \mathrm{~m} l$ の三角フラスコに取り，窒素ガスでク ロロホルムを完全に除去した後, $100 \mathrm{ml}$ の蒸留水を加え溶 解し，リノール酸- $\beta$-カロテン溶液を作成した。次にこの 溶液 $45 \mathrm{~m} l$ に $4 \mathrm{~m} l$ の $0.2 \mathrm{M}$ リン酸緩衝液（pH 6.8）を加 え，静かに攪拌した後， $4.9 \mathrm{~m} l$ を $10 \mathrm{~m} l$ 容共栓試験管に分 注し，これに $0.1 \mathrm{~m} l$ の流木木酢液ベンゼン抽出酸性部, フェノール部, 中性部 (99.5\%エ夕ノール溶液) をそれ ぞれ添加・混合し，すばやく $50^{\circ} \mathrm{C}$ の暗所でインキュベー トし，15 分毎に吸光度 $(470 \mathrm{~nm})$ を测定し，15 分後から 45 分後まで吸光度 $(470 \mathrm{~nm})$ の減少量を求めた。 
また試料溶液の色が測定結果に与える影響を考慮し，リ ノール酸- $\beta$-カロテン溶液の代わりに蒸留水を加えたもの を試料ブランクとした。

さらに BHA 溶液 $(1 \mathrm{mg} / 100 \mathrm{ml})$ を添加し, 減少量を求 め, 次の式より算出された值を抗酸化活性值とした。

\section{抗酸化活性}

$=\frac{\text { 試料 (15分O. D. }-45 \text { 分O. D. ) -試料ブランクのO. D. }}{\text { BHA (15分O. D. - 45分O. D. ) }}$

(2) DPPH 法によるラジカル消去能測定

ラジカル消去能測定は寺沢ら ${ }^{16)}$ の方法に準じて測定し た.すなわち, $2 \mathrm{~m} l$ の流木木酢液ベンゼン抽出酸性部,

フェノール部, 中性部 $(99.5 \%$ タノール溶液), $2 \mathrm{ml}$ の $0.1 \mathrm{M}$ 䣷酸緩衝液 ( $\mathrm{pH} 5.5), 1 \mathrm{ml} 0.5 \mathrm{mM} \mathrm{DPPH} /$ エ夕 ノール溶液をそれぞれ $10 \mathrm{~m} l$ 容共栓試験管に分注・混合

し, 混合直後と 30 分後に吸光度 $(517 \mathrm{~nm})$ を測定した。

また, 試料溶液の色が測定結果に与える影響を考慮し, $\mathrm{DPPH}$ ラジカルの関与しない系として $0.5 \mathrm{mM} \mathrm{DPPH/エ}$ タノール溶液の代わりにエタノールを加えたものを試料ブ ランクとし, 次の式によりラジカル消去能を求めた.

ラジカル消去能 $(\%)$

$=\frac{(\text { コントロール0分O. D. })-\{(\text { 試料30分O. D. 一試料ブランクのO. D. })\}}{\text { コントロール30分O. D. }}$

$\times 100$

\section{実験結果及び考察}

\section{1. ホルムアルデヒド及びメタノールの含有量}

流木木䣷液, ベンゼン抽出物及び残渣についてホルムア ルデヒド及びメタノールの含有量を表 1 に示した。

流木木酢液に含有されているホルムアルデヒドは 510 ppm,メ夕ノールは $0.19 \%$ であった. ベンゼン抽出物に含 有されているホルムアルデヒド及びメタノールはそれぞれ $5 \mathrm{ppm}$ 以下であり, ベンゼン抽出後の残渣にホルムアルデ ヒドが $400 \mathrm{ppm}$, メタノールが $0.15 \%$ と殆ど残存してい た. ベンゼン抽出物中のホルムアルデヒド, メタノールが $5 \mathrm{ppm}$ 以下であった理由はロータリーエバポレーターの 冷却器 $4^{\circ} \mathrm{C} \sim 5^{\circ} \mathrm{C}$, 減圧下 $140 \mathrm{mmHg} \sim 130 \mathrm{mmHg}$, 浴温 $50^{\circ} \mathrm{C}$ の条件で溶媒除去する事により僅かに移行したホル ムアルデヒド, メタノールが一緒に除去されたと考えられ る.

表 1 ホルムアルデヒド及びメタノールの含有量

\begin{tabular}{lcc}
\hline \multicolumn{1}{c}{ 試料 } & ホルムアルデヒド & メタノール \\
\hline 流木木酢液 & $510 * 1$ & $0.19 \% 2$ \\
ベンゼン抽出物 & —3 & — 33 \\
残渣 & 400 & 0.15 \\
\hline
\end{tabular}

*1 ppm, *2\%, *3 検出せず（検出限界 $5 \mathrm{ppm}$ ）
尚，抽出に用いたベンゼンは抽出物を濃縮する際，完全 に除去するため, 抽出物からは検出されなかった。

流木木酢液からホルムアルデヒド，メタノールを除去 し, 燻臭成分を抽出した精製法の特許 ${ }^{17)}$ と同様な結果が得 られた。

\section{2. 有機酸類の含有量}

流木木酢液, ベンゼン抽出物及び残渣についてそれぞれ の有機酸類の含有量を表 2 に示した.

流木木酢液には酪酸が $0.02 \%$ ，プロピオン酸が $0.13 \%$, 酢酸が $2.17 \%$ ，ギ酸が $0.10 \%$ 含有されていた。 ベンゼン抽 出物の有機酸類の含有量はいずれも $0.01 \%$ 以下であり, べ ンゼン抽出後の残渣にプロピオン酸が $0.08 \%$, 酢酸が $1.73 \%$ ，ギ酸が $0.08 \%$ それぞれ含有され，殆どの有機酸類 が残存し, 酸臭を有していた。 ベンゼン抽出物の有機酸類 の含有量が $0.01 \%$ 以下であった理由は上記 1 と同様に溶 媒除去する際，一緒に除去されたと考えられる.

\section{3. 流木木酢液ベンゼン抽出各画分の燻臭成分}

ホルムアルデヒド及びメタノールが除去されたベンゼン 抽出酸性部, フェノール部, 中性部を GCにより分析した 結果のガスクロマトグラムを図 1 に示した。

さらに GC-MS によって分析した結果, 23 種類の主な燻 臭成分が同定された（表 3 ).

酸性部には酢酸なよ゙の有機酸類は確認されず，4 種の フェノール化合物， $\gamma$-ブチロラクトンが認められた， $\gamma$-ブ チロラクトンが認められたが，今回と同様に酸性部からラ クトン類が検出された報告例 ${ }^{812)}$ あある.

フェノール部には焦げ臭さを示すグアヤコールや特有な

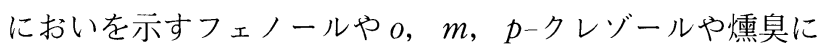
特徵を与える 2,6 -ジメトキシフェノール, 2,6 ジメトキシ -4-メチルフェノール, $4-$ アリル $-2,6$ ジメトキシフェノー ルや甘い香りのするバニリン, アセトバニロン, マルトー

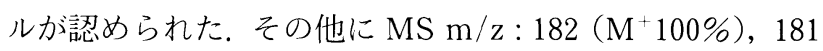
(50\%), $167(15 \%), 111(17 \%)$ を示すシリンガアルデヒ ドや MS m/z: $196\left(\mathrm{M}^{+} 58 \%\right), 181$ (100\%), 153 (13\%) を示すアセトシリンゴンが認められた。 これらもまたフェ ノール，グアヤコールと同様にリグニンの熱分解によって 生成されたと考えられる(8).

中性部にはカラメル様な香りを示すフラン類の 2-フラ ルアルデヒド，2-アセチルフラン，5-メチルフルフラール が認められ, 枯れ草様なに拈いを示すケトン類の 2-シクロ ペンテン-1-オン, 3-メチル-2-シクロペンテン-1-オン, シ

\section{表 2 有機酸類の含有量}

\begin{tabular}{lcccc}
\hline \hline \multicolumn{1}{c}{ 試料 } & 酪酸 & プロピオン酸 & 酢酸 & ギ酸 \\
\hline 流木木酢液 & $0.02 \% 1$ & 0.13 & 2.17 & 0.10 \\
ベンゼン抽出物 & — & - & - & - \\
残渣 & - & 0.08 & 1.73 & 0.08 \\
\hline
\end{tabular}

*1\%, *2 検出せず（検出限界 $0.01 \%$ 以下） 
クロテンや2-フォルミルピロールが認められた.

\section{4. ベンゼン抽出各画分の抗酸化活性及びDPPH ラジ} カル消去能

GC-MSによって同定された燻臭成分を含有したベンゼ ン抽出酸性部, フェノール部, 中性部それぞれの抗酸化活 性及び DPPH ラジカル消去能を表 4 に示した.

酸性部は抗酸化活性を全く示さず，ラジカル消去能む $30 \%$ と弱い值を示し，フェノール部は抗酸化活性 0.68 , ラ ジカル消去能 $89.0 \%$ を示し, 中性部は抗酸化活性 1.01, ラ ジカル消去能 $80.2 \%$ を示した。 中性部に抗酸化活性及びラ ジカル消去能が認められた原因として分画操作の際, 分離 が不十分であったためか，フェノール類が中性部に残存し 抗酸化活性及びラジカル消去能を示したと考えられる。

\section{5. フェノール化合物の抗酸化活性}

流木木酢液ベンゼン抽出フェノール部に抗酸化活性及び ラジカル消去能が最も強く認められたので，燻臭成分の フェノール化合物 12 種類についてリノール酸- $\beta$-カロテ ン溶液を用いた抗酸化測定 ${ }^{15)}$ を行なった。

その結果を表 5 に示した. 4-アリルー2,6-ジメトキシ フェノールは抗酸化活性 0.64 を示し， 12 種類のうち最む 強く，続いて4-エチルグアヤコールは抗酸化活性 1.00 , 2,6-ジメトキシ-4-メチルフェノールは抗酸化活性 1.01, アセトシリンゴンは抗酸化活性 1.44, シリンガアルデヒド は抗酸化活性 1.57, クレオゾールは抗酸化活性 $1.70,2,6-$ ジメトキシフェノールは抗酸化活性 2.01，グアヤコールは 抗酸化活性 2.37 の順に示した.
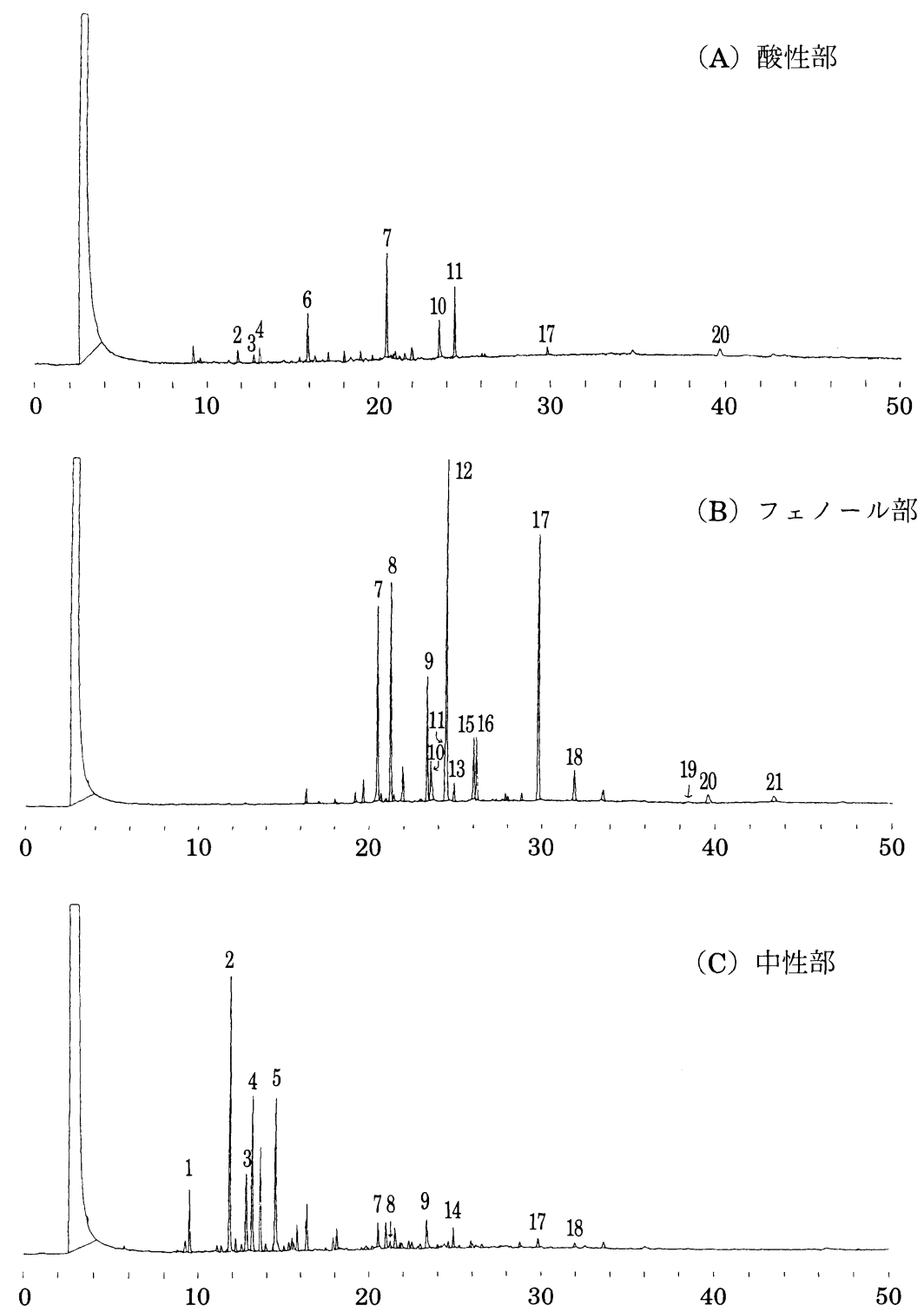

図 1 流木梗酢液ベンゼン抽出各画分のガスクロマトグラム

GC 条件: Shimadzu GC-1700（FID），カラム; CBP-Hicap（Shimadzu，I.D. $0.22 \mathrm{~mm} \times \mathrm{L} 25 \mathrm{~m}$ )， カラム温度; $60^{\circ} \mathrm{C} \sim 200^{\circ} \mathrm{C}$ $\left(5^{\circ} \mathrm{C} / \mathrm{min}\right)$, 注入口温度 ; $230^{\circ} \mathrm{C}$, 検出器温度 ; $230^{\circ} \mathrm{C}$, キャリアガス ; $\mathrm{N} 2$, Split 比 ; $1: 20$. 
表 3 流木木酢液ベンゼン抽出物の燻臭成分

\begin{tabular}{clcl}
\hline \hline $\begin{array}{c}\text { ピーク } \\
\text { No }\end{array}$ & \multicolumn{1}{c}{ 化合物名 } & 相対割合 $(\%) * 1$ & 同定 \\
\hline 1 & 2-Cyclopenten-1-one & $1.44 \pm 0.10$ & $\mathrm{MS}, t_{\mathrm{R}}$ \\
2 & 2-Furaldehyde & $4.31 \pm 0.02$ & $\mathrm{MS}, t_{\mathrm{R}}$ \\
3 & 2-Acetylfuran & $1.56 \pm 0.02$ & $\mathrm{MS}, t_{\mathrm{R}}$ \\
4 & 3-Methyl-2-cyclopenten-1-one & $2.84 \pm 0.16$ & $\mathrm{MS}, t_{\mathrm{R}}$ \\
5 & 5-MethylFurfural & $2.53 \pm 0.22$ & $\mathrm{MS}, t_{\mathrm{R}}$ \\
6 & r-Butylolactone & $3.88 \pm 0.30$ & $\mathrm{MS}, t_{\mathrm{R}}$ \\
7 & Cyclotene & $9.52 \pm 0.42$ & $\mathrm{MS}, t_{\mathrm{R}}$ \\
8 & Guaiacol & $5.79 \pm 0.38$ & $\mathrm{MS}, t_{\mathrm{R}}$ \\
9 & Creosol & $3.66 \pm 0.18$ & $\mathrm{MS}, t_{\mathrm{R}}$ \\
10 & Maltol & $3.56 \pm 0.27$ & $\mathrm{MS}, t_{\mathrm{R}}$ \\
11 & o-Cresol & $1.56 \pm 0.02$ & $\mathrm{MS}, t_{\mathrm{R}}$ \\
12 & Phenol & $11.0 \pm 0.35$ & $\mathrm{MS}, t_{\mathrm{R}}$ \\
13 & 2-Formylpyrrole & $0.21 \pm 0.04$ & $\mathrm{MS}, t_{\mathrm{R}}$ \\
14 & 4-Ethylguaiacol & $0.85 \pm 0.01$ & $\mathrm{MS}, t_{\mathrm{R}}$ \\
15 & m-Cresol & $1.76 \pm 0.05$ & $\mathrm{MS}, t_{\mathrm{R}}$ \\
16 & p-Cresol & $1.97 \pm 0.08$ & $\mathrm{MS}, t_{\mathrm{R}}$ \\
17 & 2,6-Dimethoxyphenol & $8.57 \pm 0.20$ & $\mathrm{MS}, t_{\mathrm{R}}$ \\
18 & 2,6-Dimethoxy-4-methylphenol & $1.33 \pm 0.01$ & $\mathrm{MS}, t_{\mathrm{R}}$ \\
19 & 4-Allyl-2,6-dimethoxyphenol & $\mathrm{Trace}$ & $\mathrm{MS}, t_{\mathrm{R}}$ \\
20 & Vanillin & $0.97 \pm 0.01$ & $\mathrm{MS}, t_{\mathrm{R}}$ \\
21 & Acetovanillone & $0.53 \pm 0.05$ & $\mathrm{MS}, t_{\mathrm{R}}$ \\
22 & Syringaldehyde & $1.44 \pm 0.02$ & $\mathrm{MS}$ \\
23 & Acetosyringone & $0.80 \pm 0.05$ & $\mathrm{MS}$ \\
\hline
\end{tabular}

測定は 3 回行ない, その平均值と標準偏差を示した.

*1 相対割合は溶媒ピークを除いた全ピーク面積を $100 \%$ として算出し，化合物が $2 つ$ 以上の画分から検出されたよきはその和を示した。

表 4 流木木酢液ベンゼン抽出各画分の抗酸化活性及び DPPH ラジカル消去能

\begin{tabular}{ccc}
\hline \hline 各画分 & 抗酸化活性\%1 & $\begin{array}{c}\text { DPPH ラジカル } \\
\text { 消去能 }(\%) * 3\end{array}$ \\
\hline 酸性部 & —2 & $30.3 \pm 0.09$ \\
フェノール部 & $0.68 \pm 0.03$ & $89.0 \pm 0.06$ \\
中性部 & $1.01 \pm 0.08$ & $80.2 \pm 0.11$ \\
\hline
\end{tabular}

測定は 3 回行ない, その平均值と標準偏差を示した。

抗酸化活性は数值が低いほよ゙強い

ラジカル消去能は数值が高いほよ゙強い

*1 抗酸化活性

$=$ 試料(15分O.D. -45 分O.D.) 一試料ブランクのO.D. BHA $(1 \mathrm{mg} / 100 \mathrm{ml})(15$ 分O.D. -45 分O.D.

※2抗酸化活性なし

\%3 ラジカル消去能 $(\%)$

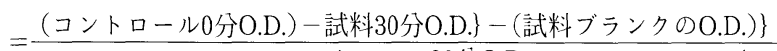
$\times 100$

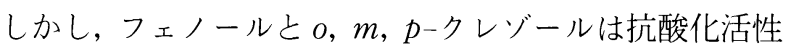
を示さなかった。

Tilgner ${ }^{7)}$ は代表的なフェノール化合物をナタネ油と ラードに添加し，その抗酸化性について検討した。その結 果フェノール化合物のうち $o, m, p$-クレゾールはナタネ
表 5 フェノール化合物の抗酸化活性及び DPPH ラジカル消去能

\begin{tabular}{lcc}
\hline \hline \multicolumn{1}{c}{ 化合物*1 } & 抗酸化活性值 & $\begin{array}{c}\text { DPPH ラジカル } \\
\text { 消去能 }(\%)\end{array}$ \\
\hline Phenol & $-\% 2$ & $-\% 3$ \\
$o$-Cresol & - & $18.7 \pm 3.82$ \\
$m$-Cresol & - & - \\
$p$-Cresol & - & $15.3 \pm 4.00$ \\
Guaiacol & $2.37 \pm 0.09$ & $85.7 \pm 0.64$ \\
Creosol & $1.70 \pm 0.21$ & $90.6 \pm 1.06$ \\
4-Ethylguaiacol & $1.00 \pm 0.04$ & $93.0 \pm 1.56$ \\
2,6-Dimethoxyphenol & $2.01 \pm 0.13$ & $78.3 \pm 1.98$ \\
2,6-Dimethoxy-4-methylphenol & $1.01 \pm 0.19$ & $88.7 \pm 0.92$ \\
4-Allyl-2,6-dimethoxyphenol & $0.64 \pm 0.02$ & $93.8 \pm 1.20$ \\
Syringaldehyde & $1.57 \pm 0.13$ & $25.1 \pm 4.88$ \\
Acetosyringone & $1.44 \pm 0.12$ & - \\
\hline
\end{tabular}

测定は 3 回行ない, その平均值と標準偏差を示した。

*1 $0.1 \mathrm{mg} / \mathrm{ml}$ に調整したものを用いた。 $*^{2}$ 抗酸化活性なし *3ラジカル消去能なし

油に対して弱い抗酸化性を示したが， $m$-クレゾールは ラードに対して抗酸化性を示さなかったと報告している.

今回のリノール酸- $\beta$-カロテン溶液を用いた抗酸化測定で

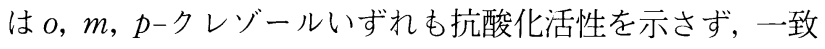
しなかった。 
さらに Pikielna ${ }^{5)}$ は燻臭成分のうち低沸点より高沸点の フェノール化合物が強い抗酸化性を示すと報告している. 今回の結果から高沸点のフェノール類化合物が強い抗酸化 性を示し，一致した。

\section{6. フェノール化合物の DPPH ラジカル消去能}

フェノール化合物 12 種類について DPPH 法を用いたラ ジカル消去能測定 ${ }^{16)}$ を行なった。 その結果, 4-アリルー 2,6-ジメトキシフェノールは消去能 $93.8 \%$ を示し, 最も強 く, 続いて 4-エチルグアヤコールは $93.0 \%$, クレオゾール は 90.6\%，2,6-ジメトキシ-4-メチルフェノールは 88.7\%, グアヤコールは $85.7 \%, 2,6$-ジメトキシフェノールは $78.3 \%$ の順に示した.

抗酸化活性を示さなかったフェノール， $m$-クレゾール はラジカル消去能む示さなかった。しかし，抗酸化活性を

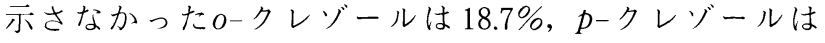
$15.3 \%$ と弱いながらもラジカル消去能を示した.

また強い抗酸化活性を示したシリンガアルデヒドの消去 能は $25.1 \%$ と弱いながらもラジカル消去能が認められ，ア セトシリンゴンはラジカル消去能を示さなかった。

\section{7. フェノール化合物の構造と抗酸化活性}

グアヤコール類のうち，4-エチルグアヤコールが最も強 く, 続いてクレオゾールが強さを示したことから 4 位に有 する $\mathrm{CH}_{2} \mathrm{CH}_{3}, \mathrm{CH}_{3}$ の違いによって抗酸化活性の強さに関 係していると考えられる．2,6-ジメトキシフェノール類の うち 2 位, 6 位に $\mathrm{CH}_{3} \mathrm{O}$ のみを有しているだけでは強い抗 酸化活性を示さず，4 位に有する $\mathrm{CH}_{3}, \mathrm{CH}_{2}=\mathrm{CHCH}_{2}$ の違 いによって強い抗酸化活性を示すと考えられる.

\section{8. フェノール化合物の構造と DPPH ラジカル消去能}

グアヤコール類や 2,6 - ジメトキシフェノール類は抗酸 化活性上同様に官能基の違いによってその強さに関係して いると考えられる.アルキルフェノール類は $\mathrm{CH}_{3}$ を有して いる 2 位, 3 位, 4 位の違いによりラジカル消去能に差が現 われたと考えられる.

全国には流木対策に苦慮している水力発電所ダムが数多 くあり，流木対策は水力発電所夕゙ムを安全に運営するため の大きな課題であると思われる.

流木を原料として製造した木䣷液は大量生産することが でき，廃棄物之して処理されてきた流木の再資源化の一つ として木酢液の原料として実用化できる事を示した。

\section{要 旨}

流木木䣷液からホルムアルデヒド，メタノールを除去す ると共にベンゼン抽出物各画分の燻臭成分とその抗酸化性 について検討した.

(1) 流木木酢液, ベンゼン抽出及び残査中のホルムアル デヒド，メタノールの含有量を測定したところ, ベンゼン 抽出物の含有量は $5 \mathrm{ppm}$ 以下であり，その大部分は残渣
に残存していることが判明した。

（2）流木木酢液，ベンゼン抽出物及び残査中の有機類の 含有量を測定した結果，ベンゼン抽出物の含有量は $0.01 \%$ 以下であり，その大部分は残査に残存していたことが判明 した.

（3）ベンゼン抽出酸性部，フェノール部，中性部から 23 種類の主な燻臭成分が確認された。

(4) ベンゼン抽出各画分のうちフェノール部に最も強い 抗酸化活性及び DPPH ラジカル消去能が認められた。

（5）抗酸化活性を示す燻臭成分のうち 4-アリル-2,6-ジ メトキシフェノールが最も強く, 続いて4-エチルグアヤ コール，2,6-ジメトキシ-4-メチルフェノール，アセトシリ ンゴン，シリンガアルデヒド，クレオゾール，2,6-ジメト キシフェノール，グアヤコールの順であり，フェノール，

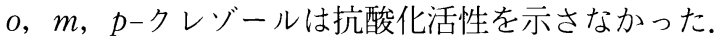

(6) DPPH ラジカル消去能では 4-アリル-2,6-ジメトキ シフェノール，4-エチルグアヤコール，クレオゾール， 2,6 -ジメトキシ-4-メチルフェノール，グアヤコール，2,6-ジ メトキシフェノールの順であり，フェノール，m-クレゾー ル，アセトシリンゴンはラジカル消去能を示さなかった。

(7) フェノール化合物の抗酸化活性及びラジカル消去能 の強さは $\mathrm{CH}_{3} \mathrm{O}, \mathrm{CH}_{3}$ の位置などによって関係していると 考えられる.

本研究に対して材料をご提供して頂いた開発工事(株) 会津営業所の皆様に深く感謝の意を表わします。

本研究は日本食品科学工学学会第 48 回（2001 年. 香 川)，第 49 回大会（2002 年. 名古屋）において発表した。

\section{文献}

1）「食品加工用 天然物便覧 第 9 版」，（食品之科学社 大 阪), pp. 144 (1986).

2）「食品衛生法改訂に伴う既存添加物名簿関係法令通知集」, 厚生省生活衛生局食品化学課編,（日本食品衛生協会 東 京), pp. 111 (1996).

3）「天然物利用による食品保存技術」，（衛生技術会 東京）, pp. 230-231 (1981).

4）太田静行，高坂和久，グュエン・ヴァン・チュエン，「ス モーク食品」，(恒星社厚生閣 東京）, pp. 56-57, pp. 125128 (1997).

5) Pikielna, N.B., Contribution of smoke compounds to sensory, bacteriostic and antioxidative effect in smoke foods, Pure and Appl. Chem., 49, 1667-1671 (1977).

6）太田静行，高坂和久，グュエン・ヴァン・チュエン，「ス モーク食品」，(恒星社厚生閣 東京), pp. 57-58（1997）.

7) Tilgner, D.J., Daun, H. and Rudnicki, A., Rapeseed Oil Used as Specific Substrate for Antioxidant Activity Investigations of Phenolic Fraction of Curing Smoke, International symposium for the chemistry and technology of rapeseed oil and other Cruciferae oil, 227-231 (1967).

8）岸本定吉, 「炭・木䣷液の利用」，(創林社，東京), pp. 248249 (1997).

9）グュエン・ヴァン・チュエン，加藤博通，〈ん煙フレー 
バー研究の現状 (その 2), 日食工誌, 30，722-728 (1983).

10）「わかりやすい 食品衛生の手引」, 食品保健研究会編, (新 日本法規出版 名古屋), pp. 129-131, pp. 1122（1999）.

11）谷田貝光克, 雲林院源治, 太平辰朗, 炭化副産物に関する研 究 (第 4 報), 木材学会誌，34，184-188（1988）.

12) Yasuhara, A., Sugiura, G., Volatile Compounds in Pyroligneous Liquids from Karamatu and Chisima-sasa, Agric, Biol. Chem., 51, 3049-3060 (1987).

13）城代 進, 矢野省一, 上原徹, 木酶液の成分とその諈香, 木材学会誌，35，555-563（1989）.

14）「衛生試験法・注解」, 日本薬学会編, (金原出版 東京), pp. 661-662 (2000).
15）津志田藤二郎, 鈴木雅博, 黒木柾吉, 各種野菜類の抗酸化性 の評価および数種の抗酸化成分の同定, 食科工，41，611618 (1994).

16）寺沢な抢子, 山崎 希, 福井優美子, ハーブ水抽出成分の抗 酸化活性, 食科工，48，99-104（2001）。

17）開発工事(株), 高品質木䣷液原料の製造方法, 特許第 3002166 号 (1999.11.12).

18）松井隆尚, 松下洋一, 菅本和寬, 田中達成, 李 元祥, カシ 材, スギ材抢よび夕ケ材木酷液の成分分析, 宮崎大学工学 部研究報告, 27, 57-61 (1998).

(平成 15 年 3 月 3 日受付, 平成 15 年 8 月 11 日受理) 